\title{
Online Advertisement of Semarang's Cuisine: An Analysis of the Affect Devices
}

\author{
N Setyawati ${ }^{1}$, Riyadi Santosa ${ }^{2}$, Sumarlam ${ }^{3}$, Dwi Purnanto ${ }^{4}$ \\ ${ }^{1}$ Universitas PGRI Semarang, Semarang, Indonesia \\ 2,3,4 Universitas Sebelas Maret, Surakarta, Indonesia \\ E-mail: n.setyawati.71@gmail.com
}

\begin{abstract}
The advertisement language is an aggressive communication. An advertising stuff as a text is a sign system organized according to codes that reflecting values, attitudes, and beliefs. Each message in the advertisement has two meanings: explicitly and implicitly meanings. Thus, interpersonal functions become an appropriate process for knowing the meaning that is in the advertisement. This research will focus on the Semarang's cuisine advertisements on the Internet. The problem of this research is how does the affect devices in the text of cuisine advertisement in Semarang. This study hopefully can be useful for: (a) describing the affect devices that created Semarang cuisine advertisement texts; and (b) mapping the appraisal system in Indonesian advertisement texts, especially the affect devices in the Semarang cuisine advertisements. This study uses a qualitative approach. The data source in this study taken from the Internet. The sampling technique used in this study was purposive sampling. The data analyzed one by one based on content analysis using the stages of content analysis by Spradley [1], which consisted of domain analysis, taxonomy, complementary, and cultural topics. The affects that contained in the Semarang cuisine advertisement texts can be categorized as positive affects. This positive feeling can be expressed directly through emotional conditions (emotional states), physical expression, and indirectly (implicitly) through metaphors.
\end{abstract}

Keywords: Online Advertisement; Semarang; product

\section{INTRODUCTION}

Advertising is a form of indirect communication that is based on information about the advantages or benefits of a product, which is arranged in such a way as to create a pleasant feeling that will change one's mind to make a purchase [2]. Advertising as a text is a sign system 
organized according to codes that reflect certain values, attitudes, and certain beliefs. Each message in the ad has two meanings, namely the meaning expressed explicitly on the surface and the meaning expressed implicitly behind the surface of the display ad [3]. Thus, interpersonal functions become the appropriate analysis to find out the construction of the meaning contained in the advertisement.

Advertising is part of the promotion mix and the promotion mix is part of the marketing mix. So, advertising can be interpreted as a message that offers a product aimed at the community through a media [3]. The development of information technology has been very rapid in the last few decades. On all fronts of life, there are almost various internet services that adorn. This digital disruption phenomenon cannot be denied, everyone must follow this progress. This is also captured by every party in various fields or industries, one of which is the owner of the product whose advertisements want to be displayed on the internet. The forms of online advertising that are presented also vary, for example online ads that are very simple with concise, solid, and clear words. There are also online advertisements that are conceptualized in depth with words that are intriguing, but full of meaning.

Currently advertising on internet media has become a driving force in advertising efforts. Along with the increasingly widespread use of the internet, the internet has become a medium of advertising for marketed products. Internet media provides convenience and flexibility that are not obtained when placing advertisements in other media. The advertisers will pair their advertisements on potential publisher websites, which are visited by visitors.

This study aims to provide a complete description of the affect devices that build text of typical cuisine advertisement in Semarang. It is hoped that this research will be useful in helping to map the appraisal system in Indonesian ad text, especially for devices that affect the typical cuisine advertisement of Semarang. Affect is part of the rating system. Martin [4]mentions the existence of three domains in the scoring system, namely: a) attitude in attitude (attitude), b) amplification or graduation in assessments (amplification or graduation), and c) sources of judgment (sources of attitudes or engagement). Attitudes related to three types of evaluations of: a) affect (affect or feelings), b) judgment (judgment), and c) appreciation (appreciation). From several studies that can be used as references by researchers to conduct this research are[5]-[8]

If the meaning of the text is identified as a whole, the position of appraisal in the interpersonal area as explained by Martin \& White [9]that on one side of the assessment is seen as a system and on the other hand the assessment is seen as a term in the assessment itself. Development of assessment theory can answer the challenge that so far research on interpersonal meanings has been more oriented to the interaction process than to ways of sharing feelings [9].

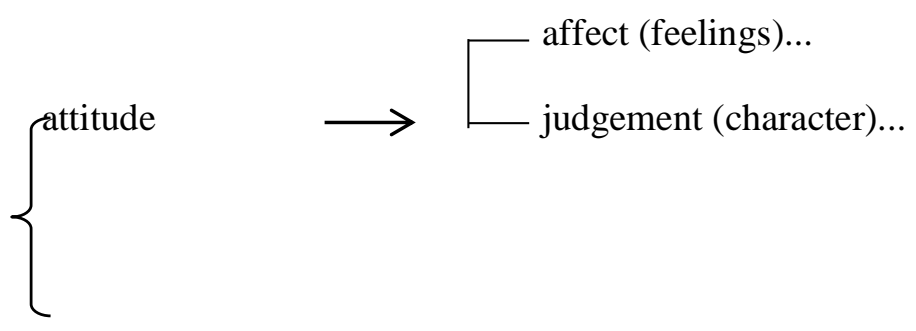


Appraisal amplification...

sources...

(adapted by Martin \& Rose, 2003:25)

Figure 1. The Basic System of Appraisal

Affect is related to the assessment of an emotional reaction to something (someone, object, or something that is happening). What was explored involved how to express feelings in the text.

\section{METHOD}

This study uses a qualitative approach. The discourse analysis approach was applied in this study, which was stated descriptively. The data source in this study is the internet virtual space. The data in this study are online advertisement text of Semarangan's cuisine (a bunch of foods, side dishes, vegetables, drinks, and snacks), which are uses the affective devices. The sampling technique used in this study was purposive sampling. Meanwhile, the data were analyzed one by one based on content analysis, in this case using the stages of content analysis Spradley [1] which consisted of domain, taxonomic, compositional, and cultural themes analysis. This study also uses domain analysis.

The taxonomic analysis is done to classify the types of ad text affective. Taxonomic analysis like this of course will be influenced by the approach and depth used by the researcher. The type of affection will be classified into a more specific division. This division can be seen in table 1 below.

Table 1. Classification of the affect devices

\begin{tabular}{ccc}
\hline \multirow{2}{*}{ positive } & direct & feeling expressions \\
\cline { 2 - 3 } & indirect & physical expressions \\
\cline { 2 - 3 } negative & direct & unconditional attituded \\
\cline { 2 - 3 } & indirect & feeling expressions \\
\cline { 2 - 3 } & & unconditional attituded \\
\hline
\end{tabular}

The next analysis is compound analysis, which is an analysis that connects all categories of domains and taxonomies. The categories in question are: main food, side dishes, vegetables, drinks, snacks. The types of internet media used include: websites, sponsorships, and classified ads. Meanwhile, the devices used are positive and negative, both directly and indirectly, involving feelings of expression, metaphor, and physical expression. 
The main objective of analyzing cultural themes is to explain and discuss the types of affect on cuisine ad text. In the analysis of cultural themes, the researcher interpreted the use of affective types in various texts obtained in compound analysis. Analysis of cultural themes will be based on the context of the situation and cultural context to explain the use of affective types in cuisine ad text. Therefore, a related theory review, review of related research, and the context of its use becomes very vital.

\section{RESULTS AND DISCUSSIONS}

Advertising as a text is a sign system organized according to codes that reflect certain values, attitudes, and certain beliefs. Each message in the ad has two meanings, namely the meaning expressed explicitly on the surface and the meaning expressed implicitly behind the surface of the display ad [10]. Likewise, with online advertising, the forms of online advertising that are presented are various. There are very simple online advertisements with concise, solid, and clear words. There are also online advertisements that are conceptualized in depth with words that are intriguing, but full of meaning. Advertising is a marketing communication effort both goods and services carried out by individuals, groups of companies, or government bodies to prospective consumers through various media, one of which is the medium internet (online).

The advertisers will set criteria when going to advertise, which is determining the content of the website. The contents presented by advertising on the internet can be very diverse. A web or blog with interesting content will make internet users come many times because they are interested in the content, so that a website can be popular on the internet [9]. Effective internet advertising is advertising that can provide a response, both directly and indirectly, from consumers. An internet advertising in providing direct response from consumers has several features to support it.

In this study the authors found several texts that use affect. This can be seen in the following data.

(1) "Menu khas Semarang ini bahan utamanya adalah tahu goreng dan gimbal, dengan rajangan kol, lontong, tauge, dan telur goreng. Siraman sambal kacang membuat menu ini 'makin sempurna' rasanya. Bagi yang belum tahu, gimbal adalah semacam bakwan goreng yang berisi udang, tambahan gimbal inilah yang bikin menu ini 'jadi khas'.” (http://hellosemarang.com/4-kuliner-khas-yang-bikinkangen-semarang/)

Cuisine adverts of the typical Semarang staple food contained in the text (1) use the expression of positive feelings directly with these phrases: "makin sempurna" and "jadi khas". Producers intelligently attract sympathetic cuisine consumers to know their gimbal with the expression "makin sempurna". The perfection of the taste expected by consumers will be able to be captured by the expression. The exact use of the expression "jadi khas" is written in the text because we all know that gimbal tofu is a typical cuisine in Semarang.

(2) “Es Cong Lik menyediakan 'banyak sekali' pilihan es puter seperti es puter cokelat, kopyor, leci, sirsak, kelengkeng, blewah, alpukat, kacang dan durian. Pilih saja sesuai selera Anda karena 'semua sama lezatnya'." (https://tempatwisataunik.com/info-wisata/wisata-kuliner/wisata-kulinersemarang) 
In text (2) is an example of cuisine text of a typical type of Semarang's drink. The text uses positive affection directly with the expression of feeling using the phrase "banyak sekali pilihan" and the phrase "semua sama lezatnya". The owner is very creative in getting food lovers to enjoy the Es Cong Lik dish with the phrase "banyak sekali pilihan". No less important is the producer also expressing his feelings with the phrase "semua sama lezatnya". The phrase is enough to tempt consumers to experience the cuisine delights offered by coming to the cuisine place.

(3) 'Lumpia di Semarang terkenal 'sangat enak'. Lumpia adalah perpaduan rasa antara Tionghoa dan Indonesia. Biar rasanya 'tambah enak', kita bisa mengasihkan cabai dan acar asam, jadi rasanya 'tidak akan terlupakan'." (https://sahabatnesia.com/makanan-khas-semarang/)

A typical snack in "Lumpia City" (Semarang) is spring rolls. Text (3) is a direct expression of positive affect with phrases "sangat enak", "tambah enak", and "tidak akan terlupakan". The presence of these phrases can quite win the hearts of the consumers of this one snack. The customers can imagine something that tastes good will be able to make anyone who has ever felt it will not forget it.

(4) "Wingko babat ini 'sangat cocok' dijadikan buah tangan bagi Anda yang baru saja berkunjung ke Semarang." (https://tempatwisataindonesia.id/makanan-khassemarang/)

In text (4), the type of cuisine snack has a direct positive affect with use the feeling of the phrase "sangat cocok". Producers with their journals convey to consumers that the cuisine snack wingko tripe production is one of the souvenirs when visiting Semarang which is suitable to buy.

Based on the results above, there are many positive affects that are expressed directly by expressing feelings through several phrases. The phrases are: (1) "makin sempurna" [perfecto] and "jadi khas" [an unique one]; (2) "banyak sekali pilihan" [many choices] and "semua sama lezatnya" [same tastes]; (3) "sangat enak" [very delicious], "tambah enak" [more delicious], and "tidak akan terlupakan" [memorable]; and (4) "sangat cocok" [very suite for the tongue]. Those phrases are taxonomized by design of positivism. The owners want to give values that every one, every customer, always remember the words/phrases. By means, the owner successfully communicates the values of their products indirectly through the phrases.

The business owners use online advertisements to introduce products that they market to a broad audience. The online advertisement contains something that will be offered, offered, or sold. In order to offer and attract the readers' attention, disclosure in online advertisements is made in such a way that the readers are persuaded to want to buy the goods or services offered [11]. The online advertisers have several goals in designing each ad. Setting goals is done so that the online ad is on target and becomes an effective advertisement. According to [12] advertising as a form of commercial letter has the purpose of: making direct sales, fulfilling the demand for production services, giving and testing reactions to production results, reaching company prospects, maintaining and growing agency, and having good faith.

The advertising goals must flow from previous decisions regarding the target market (the intended target), market positioning, and marketing programs. These advertisements can be classified as: informative advertisements, persuasive advertisements, reminder ads, and reinforced advertisements [13]. Basically, the purpose of advertising is to attract the attention 
of consumers to read or listen to advertisements, then comes the belief that the goods or services are the right choice and ultimately give birth to actions to buy and use the goods or services. To accommodate this, indirectly, business owners have online advertised using a number of positive effects so as to produce positive impressions for customers and potential customers. In an attempt to trace the history of the product life cycle conceptualized in advertisement about The Advertising Spiral[14] that most products passed through the stages of pioneering, competitive, and retentive. It is clearly illustrated in Kleppner's statement that the stages of advertising based on the product life cycle stages of most products go through the stages of pioneering, competitive, and retentive. These three stages must be passed by an online advertisement when it comes to consumer awareness (online ad target).

\section{CONCLUSION}

The conclusion of this study is that the affect devices contained in the online advertisement text of Semarang locally cuisine can be categorized as positive affects. These positive feelings can be expressed directly through emotional conditions and physical expression indirectly through metaphors.

\section{REFERENCE}

[1] S. JP, Participant Observation. New York: Holt, Rinehart, and Winston, 1980.

[2] F. Tjiptono, Pemasaran Jasa. Malang: Bayumedia Publishing, 2005.

[3] R. Kasali, Manajemen Periklanan: Konsep dan Aplikasinya di Indonesia. Jakarta: Pustaka Utama Grafiti, 1995.

[4] J. R. Martin and D. Rose, Working with Discourse: Meaning beyond the Clause. London and New York: Continuum, 2007.

[5] A. M. Nur and A. S. Hadi, "Realisasi Appraisal dalam Aspek Attitude pada Media Online Instagram,” J. Sasindo Unpam, vol. 3, no. 2, pp. 15-25, 2016.

[6] P. A and et al, "Analisis Sistem Appraisal Berita Proses Eksekusi Duo Bali Nine (Pendekatan Linguistik Sistemik Fungsional)," Paramasastra, vol. 4, no. 2, pp. 193208, 2017.

[7] G. Ritzer and D. J. Goodman, Teori Sosiologi Modern. Jakarta: Kencana, 2008.

[8] R. Tiani, "Judgement sebagai Sistem Appraisal dalam Iklan Kecantikan Visual Media Cetak," Nusa, vol. 12, no. 4, pp. 256-264, 2017.

[9] J. R. Martin and P. R. R. White, The Language of Evaluation (Appraisal in English). New York: palgrave macmillan, 2005.

[10] R. Noviani, Jalan Tengah Memahami Iklan. Yogyakarta: Pustaka Pelajar, 2002.

[11] Z. Arifin, Pemakaian Bahasa dalam Iklan Berita dan Papan Reklame. Jakarta: Pusat Pembinaan dan Pengembangan Bahasa Departemen Pendidikan dan Kebudayaan, 2000.

[12] R. Shurter, Written Communication in Business. New York: McGraw Hill, 1971.

[13] P. Kotler and K. Keller, Manajemen Pemasaran. Jakarta: PT Indeks Kelompok 
Gramedia, 2007.

[14] O. Kleppner, Advertising Procedure. New York: Prentice Hall Inc, 1931. 